\title{
Answers in the wind: using local weather studies for family history research
}

\author{
Malcolm Noble
}

\begin{abstract}
Records of local weather events are a neglected resource for historians wanting to explain family events and family patterns. In the UK, the collation of weather reports commenced in 1860, Gordon Manley's work in the 1950s produced the Central England Temperature series from 1659, and the National Archive and National Meteorological Archive hold many individual records, including over a thousand private weather diaries. The family historian can use documents associated with the parish chest to support the investigative cycle of research, analysis, hypothesis and proof. With that method in place, explanations can be developed from accessible and easily understood sources. The process leads us towards a closer understanding of our ancestors' relationship with their world - the weather is an experience which we share with them, and a broad awareness of the local climate can provide a means of 'colouring in' their lives.
\end{abstract}

Received: 2 June 2017

Accepted: 8 August 2017

Additional information is available at the end of the article.

KEYWORDS: Cambridgeshire; Central England Temperature (C.E.T.); Tudor; wills; probate; sources; storm

\section{Introduction}

There cannot be a local history journal that has not published at least one story of their town or village's 'Great Storm'. Snow, flood and gale fall so easily into folklore that the traditions of any parish can hardly be recited without mention of them. These spectacular events mean that the link between weather and local history has become well established, but few family historians bring the elements fully into play; certainly, weather is not seen as an essential consideration to be covered when piecing together the lives of our ancestors.

By exploring this link, this article will add one more worthwhile option to the armoury of the family historian who is seeking to explain not only family disruption but also some of those peculiar comments found in wills, registers and vestry ephemera. The value goes much further than simple problem solving. We will be working towards a closer understanding of our ancestors' relationship with their world, and - in that very rare instance where we might be able to identify how the weather affected them at a particular time and place - that understanding can be like a truth come home.

\section{Data sources}

Having argued that the weather deserves a place on the family historian's agenda, I will offer some reassurance about the availability of information (focusing on sources before the commencement of national data collation in 1860).* I will show why a systematic approach and a made-to-measure recording method are especially important to the subject, and I will conclude with some thoughts on the analysis of family disruption following a weather event. For two reasons, I will concentrate on the Tudor and Stuart periods with an occasional nod to later times. Firstly, those reigns are more challenging when it comes to both comparable data and the availability of sources. And secondly, when our research takes us beyond the commencement of parish registers, any research that provides colourful detail about our forefathers seems especially welcome. But the proposed discipline applies to any century; it is only the comfort that varies.

Comments in parish registers carry the taste of catastrophe. When John Southerden Burn researched his History of Parish Registers in England (published in $1829^{1}$ ), he found many examples of weather events weighing down on local economies. A storm in Frampton-on-Severn 'in the space of four hours, destroyed twelve barns, one dwelling house and rooted up 357 trees, mainly in orchards' (18 February 1662$).{ }^{2}$ Another entry laid out the consequences for the parish of Youlgrave in Derbyshire in 1614:

*The National Meteorological Archive holds daily weather reports from 3 September 1860. 
Hindrances and losses in this peak country by the snow aforesaid. 1. It hindered seed time. 2. It consumed much fodder. 3. And many wanted fuel, otherwise few were smothered in the fall or drowned in the passage. ${ }^{3}$

The same register reports the effect of drought in the following year:

The greatest part of this land, especially the south parts, were burnt up, both corn and hay. An ordinary summer load of hay was at $2 \mathrm{l}$ and little or none to be got for money. 4

These and similar details provide the family historian with an opportunity to 'bring home' these events and tell the story in terms of the individuals and families concerned. At its most dreadful, a weather shock could threaten house and limb. Far from the capital, a note in the vestry book for St Oswald, Durham, on 24 May 1613, conceding that the 'earthquake book' cannot be accounted for, might be the first step on a trail leading to the order of prayer distributed following the London earthquake of 6 April $1580 .{ }^{5}$ But these instances are rare. Even the lesser events, affecting work opportunities or prompting the vestry to raise additional funds for the repair of parochial property, are uncommon. Their frequency hardly justifies detaching each grandparent and researching how the weather affected his or her life, but the consequences of a weather incident can be sufficiently far-reaching that, where there is evidence of family disruption or a change in a family's social profile, the weather should be one of the explanations that the genealogist will want to test. The wind and rain can also add to those stories where, at first glance, they seem to have no part to play; in fact, it is probably those occasions when they bring most texture to the story. This is finely illustrated by an example from Tudor Cambridgeshire. The burial register from Bottisham in Cambridgeshire ${ }^{6}$ tells a familiar story:

Alice wife of Thomas Noble buried 25 Oct 1570.

Ann daughter of Thomas Noble buried 25 Nov 1570

By this time, the plagues which had troubled the county throughout the 1560 s were thinning out, although instances of the sickness continued into the 1570s. Certainly Bottisham was suffering a high death rate at this time. The year of 1570 is the first complete year of the Bottisham register to survive, so comparisons are difficult. However, the sixty-four burials for the years 1570-2 were more than double the twenty-nine burials for 1574-6. On the face of it, it seems that research into prevailing weather could add little to the picture. But we know that 1570 was the year of the Great Surge in the North Sea, with storms battering East Anglia through October and November. ${ }^{7}$ (Buckinghamshire's Member of Parliament lost the greater part of his livestock during the storms. ${ }^{8}$ ) And so, no matter how reluctant we might be to attach any importance to the weather at the time of these two deaths, and a troubled childbirth must remain a probable cause, the picture of a distressed and ailing family is enhanced by a raging storm outside. Probably, having heard the story, it is the factor we are most likely to remember, because we can recognise the weather - we know how it feels to be indoors with the wind, rain and cold outside; we know how it feels never to be completely dry; we know how bad weather can seem like that one extra thing that is against us when times are tough. In this way, weather study can put us in touch with those characters who populate our family story.

Sometimes the genealogist will want to work in the opposite direction. Rather than identifying a possible consequence (two deaths in a family) and looking for the cause (a harsh winter), a note on a leaf of the parish register might mention the harsh weather or, more commonly, a storm or freeze, and we might want to examine the different branches of the family tree for any possible effect. For example:

On 27th November 1703 was the greatest hurricane and storm that ever was known in England; many churches and houses were extremely shattered and thousands of trees blown down. Thirteen or more of her Majesty's men of war were cast away and two thousand seamen perished in them. NB The storm came no further north than Great Yarmouth. (St Oswald, Durham) ${ }^{9}$

Similarly, the diary of Samuel Newton, Alderman of Cambridge, records a storm for 26 November 1703 that ' ... killed by the fall of chimneys much people'. ${ }^{10}$

A detailed consideration of village superstition about the weather would be beyond the scope of this article. However, since we are considering how the weather influenced the lives of our ancestors, a note in a Dorchester register for 22 August 1651 signifies how parish officers found it difficult to disassociate the coincidence of worrying events:

At night, there was a great thunder such as had not been known by any living in this age and there fell a great storm of hail, some of the stones of which were seven inches about with abundance of rain and it continued all night and great part of next morning till 8 or 9 of the clock. That same day Mr Love and Mr Gibbons beheaded. ${ }^{11}$ 
At first, the family historian might be daunted by the prospect of researching local weather incidents before the introduction of national recording. However, the importance of weather to local affairs meant that weather incidents were probably the most likely to find their way into the parish books. The puzzle, if there is one, grows from the diversity of documents in which the storm, gale or flood might have been recorded. One example from Worcestershire Record Office (now the Archive and Archaeology Service) illustrates the serendipity of the search. In 1947, a schools inspector kept a record of his visits to schools in Suffolk and Cambridgeshire to assess geography teachers and their facilities and equipment. At the time, some people might have felt that including a journal of the weather during these excursions was an abuse of his report book. Now, those notes are part of the national memory. ${ }^{12}$ These personal diaries often remind us how fearful people could be of the weather:

13 October 1666, North-west part of the heavens (in my thoughts) seemed many times to burn and be all of a red fire. It came after the manner of lightning but the flashes much more red (even as fire), also much more large and of longer continuance. ${ }^{13}$

Before exploring further, we need to settle the distinction between weather and climate, not because understanding one is less valuable than understanding the other, but if we convince ourselves that we are analysing weather when we are considering only climate, the results will not only be flawed but will be unlikely to indicate any conclusion of substance. The United States National Aeronautics and Space Administration provides a nicely unambiguous definition:

The difference between weather and climate is a measure of time. Weather is what conditions of the atmosphere are over a short period of time, and climate is how the atmosphere 'behaves' over relatively long periods of time. ${ }^{14}$

I prefer to personalise the distinction. Put simply, the climate is what our forebears expected; the weather is what turned up. If the weather was expected, it reinforced the routines and conventions of family life. If it came as a big enough surprise, it could disrupt those lives to an extent that no family historian should leave unexplained.

Although researchers may be eager to bury themselves in the contents of the parish chests, the UK's National Archives and National Meteorological Archive must remain the first ports of call, if only for the power of their search engines. The National Meteorological Archive has over a thousand (mainly private) weather diaries, which comprise the greater body of their information before 1820 . For an overview of the more structured research, we have two authoritative papers by Gordon Manley. ${ }^{15,16}$ Manley presented many years' research to suggest mean temperatures month by month in central England since 1659. He completed this survey by bringing together series of records made at the time, and so not only summarised the work of the pioneers of weather recording but also suggested some compensations for their shortcomings (which were often no more than the consequence of lacking co-ordination in the early days). The product of his work is recognised as the Central England Temperature (C.E.T.). There is much technical content in these two papers but the tables and diagrams should not deter family historians seeking to chart their way through the different weather surveys - they will be adding to their background knowledge and picking up clues to sources.

\section{Parish histories and records}

County Record Offices and municipal reference libraries take us towards more regional and local sources. Here, you would be unlucky if a review of work already undertaken by others does not produce at least an overall view. I have already mentioned local history journals. Every parish history is likely to refer to weather incidents. In his short history of Bingham in Nottinghamshire, John Chettle Wood referred to the bad weather in the winter of 1785 which prompted some young men of the town to put on a play for the benefit of the poor. The cast list survived and nine families (including Wood's) are now able to trace their links to the amateur theatre of Georgian England, while genealogists with a broader interest in the county may have picked up a clue about the circumstances of that winter.* I would also encourage a look at student dissertations (many now available online). It seems that weather has long been a tempting avenue to study when research is necessarily locally based.

Indicators about parochial weather history for the period of the earliest parish registers (and further back) are more likely to be found closer to the ground. To say that the genealogist must search everywhere and anywhere hints at why the quest might attract the burrower as much as the researcher with a more scientific approach. When it comes to looking for primary sources from the parish chest - and this is where the best evidence is likely to be found - the more free narrative which the document contains, the more likely it is to bear fruit. It is in the free narrative of the marginalia rather than the bare details of baptisms, marriages and burials that disruptive weather is mentioned. Few examples can match the seventeenth-century register for Alrewas in Staffordshire which Burn described as 'for several years a most complete journal of the

${ }^{*}$ Wortley ${ }^{17}$ relates the episode acknowledging Wood (1870-49) who appears to have worked from family documents (including theatre bills). Wood's pamphlet unseen. 
weather, storms, floods and other parochial occurrences'. ${ }^{18}$ From the parish chest (the contents of which will now be in the County Record Office, almost certainly), the churchwarden's account might include details of repairs to the church fabric and grounds following a storm. In 1608 , Great St Mary's in Cambridge 'paid to two men for fetching the stones of the leades which were blown down in the great wind xij $d^{\prime}$. 19 The vestry minutes might offer weather comments from Tudor waymen, woodwards, haywards and hedge-lookers as well as measures to draw in funds to make good weather damage. Overseer accounts might show special pleadings from, and grants to, paupers on account of harsh winters or dry summers. The charm of these vestry documents is that they know no rules. Comments and reports that you expect to find in one document might appear in another, or both.

\section{Wills}

In rural communities, where comforts were dependent on the harvest, a close examination and interpretation of Tudor or Stuart wills may hint at the effects of the weather. Here, I recommend especially close attention be paid to changes or allowances made in codicils (often close to the death); these additions should prompt the genealogist to ask what has changed since the original will was composed. Of course, many developments can change the fortunes of a family, but a windswept or rain-drenched harvest is certainly one that should be considered.

The will of one Cambridgeshire yeoman provides an example of how the weather can force itself into our analysis of a deceased's circumstances and legacy. William Tassell, a yeoman of Balsham, was well off. When he died in 1574 he left most of his estate to his son and his widow. ${ }^{20} \mathrm{He}$ allowed his son twelve months to realise many of the assets bequeathed to the widow - a common enough measure in rural communities where a man's wealth had been tilled into the soil and could not be harvested until the season allowed. Tudor patriarchs (and matriarchs) liked to use their wills to rule from the grave. William had tried to protect his wife's interest in the farm's wealth, if not the farm. Analysis of the will concentrated on the nine tons of corn left to his wife (to be drawn from the upcoming harvest). A quick look at Hoskins' article on harvest fluctuations ${ }^{21}$ promised interesting ground. Although the years 1566-71 had seen good harvests, 1573 was notoriously bad; in fact the Privy Council ordered an enquiry into corn stocks in the City of London. The east of England fared better than the west, but 1573 would still be followed by four years of below-average harvests. William Tassell wrote his will in July 1574 and would have foreseen another poor year. It was with this perspective that he decided how his son and widow should share the risk of the bad harvest. If he had expressed the bequest as a fraction of the harvest produce or specified that his wife should receive the income from a particular field, news of a good or bad harvest would have been felt, proportionately, by both of them. But William specified an amount of corn. By July, he would have been confident that the price was not going to fall much below an average figure and was likely to be higher. If the harvest was poor - as he would already have expected - then the nine tons would have been a greater than normal proportion of the harvest (and difficult for his son to endure) while his widow would have benefitted from the resulting high price.

There is good evidence that William Tassell was an astute operator. He was of good English yeoman stock. He had at least five horses, and his house was well furnished with at least two beds, one with a flight. Three chests were in his bedroom and he also had a best red chest. We know that he had other furniture and a good show of pewter and brass (but no mention of silver). He was well read. He had been a parish clerk. He had an interest in astrology, drew horoscopes and told fortunes and also had a reputation as a wizard. ${ }^{22}$ He had experience of acting as a scribe and executor for wills. He would have known what he was doing when he drew up these provisions for his widow and, thanks to our taking account of the weather, we are able to understand his thinking.*

\section{Walking the ground}

The final source for research (or perhaps it should be the first?) is walking the ground. There are, of course, numerous books on fieldwork in local history but, because I have been doing it for some years, I tend to fall back on old favourites, W. G. Hoskins especially. Field names and road names can be lifted from the maps but an afternoon dawdling around the parish, noting the area that might be prone to flood or drifting snow or exposed unfairly to the wind and rain, might not only bring us closer to the village that our ancestors knew but also provide a structure when we try to analyse and contextualise information.

\section{Conclusion}

This article has focused on alerting the genealogist to the degree that weather might have an impact on our understanding of sudden and unexplained changes in the family timelines. So we have been looking for operational, rather than strategic, intelligence. But if the subject family has been evident in a borough or hundred for, say, four or more generations, then the genealogist may be interested in a broad understanding of the local climate through those hundred years, not only as a means of 'colouring in' the lives of those who lived in the

${ }^{*}$ My assessment draws on Tassell's will and the sketch in Marsh. ${ }^{23}$ Marsh provides an insightful assessment of Tassell's life (and especially his part in the Family of Love sect). However, he seems to identify Wm Tassell, yeoman of Balsham, with Wm Tassell, the benefactor of Bury St Edmunds. I think that link will be better established when it can be reconciled with the Herald's Visitation to Suffolk in 1561 which gives an alternative view of the subsequent genealogy. ${ }^{24}$ 
parishes, but also as background knowledge with which to meet any incidental questions that may crop up. Certainly, your genealogical research will be better directed if you carry with you the years of bad harvests, harsh winters or the Great Storm.

Whether we realise it or not, genealogy naturally draws us into a sequence of research, analysis, hypothesis and proof. Experienced practitioners might smile at that last step since they spend more time and effort trying to disprove a hypothesis than accepting proof of it. There are temptations here. Evidence about local weather four centuries ago is sufficiently scarce that we might be ready to promote circumstantial or supporting evidence to grade one. And we will have worked so hard looking for the evidence and finding little that we might be ready to accept that things must be so because we have found no evidence that they weren't. Let no family historian pretend that they have never been tempted by short cuts. We are always ready to race ahead - sketching out a hypothesis based on a coincidence of two stray facts - but let us be clear that before any hypothesis can come alive it must be tethered to analysis and through that stage to the primary research. This discipline is especially important when we are exploring the weather. It is a project that might take us years and we must maintain the step-by-step approach.

Information about weather relevant to a genealogy is likely to come forward only a little at a time. It is, therefore, especially important that record-keeping can service a longer than medium-term project. When Iredale ${ }^{25}$ recommended methods for recording and storing stray information fifty years ago, he spoke about index cards where nowadays we might be thinking of spreadsheets or databases. But the thread of Iredale's advice remains valid. A recording method should be designed to meet the needs of the research project. Information should be recorded according to that system. Recording different aspects of weather information in different ways will not prepare the records for analysis (which must be the eventual purpose) but make that analysis more complicated, if not confused.

When the research, analysis, hypothesis and proof have convinced the genealogist that weather influenced an episode in a family history, he or she is then equipped to research the effect on the family. Here, the indicators of a resulting change in the family's social profile appear similar to those evidenced in the effects of enclosure. Was the self-employed thatcher reduced to accepting employment as a labourer? Did the family migrate? Did branches of the family move in with one another? The genealogist will want to compare the standing of marriage partners before the event with choices made two generations later. Similarly, a comparison of family circumstances (and the father's occupation) may be made between generations when the second child is ten years old. These broad-brush measures are useful first steps when assessing changes in the social profile of a family.

I hope I have shown that weather needs to be taken seriously and, while researching weather before systematic recording was in place may at first seem a forlorn hope, many rich sources are available. Notwithstanding the importance of a systematic search, the family historian benefits from sweeping up stray information about weather in the hundred of their interest. The likely fractured nature of such research reinforces the need for a clear distinction between analysis and hypothesis and the other stages of the investigative cycle. And so we can see that researching weather history reinforces the imaginative and disciplined ingredients of the typical family historian; we see the attractive combustion of genealogy made all the better because the product is likely to add colour and depth to our family story. The research is worth doing because the weather is an experience which we share with our ancestors and it is part of their world which we can understand. As they did, we look skywards and try to predict it. We tell our children the folklore of thunder and lightning. We look crestfallen when the weather has spoilt things and frightened when its ferocity takes us by surprise, just as they did.

But there is work still to be done. It was once a truth universally acknowledged that the quality of a genealogy bore no relationship to the time invested. Although the progress of the last fifty years is now threatened by the ease with which genealogies can be shared unchecked, the disappointment of the old dictum is no longer so general. Thanks to the work of W. E. Tate in the 1950s and 1960s and a series of television programmes in the 1970s, enthusiasts were brought to the work with different objectives and a more educated approach to the scientific interpretation of evidence. Indeed, the old dictum can almost be placed on its head: only a tentative genealogy can be produced within a medium term of years. Many of those baby-boomer enthusiasts will have followed Iredale's advice (his book was a staple guide at the time) and now fifty years' worth of notebooks, card indexes or home library slips (not to mention the work by groups) are lying at the bottom of Grandma's wardrobe or in the attics of eccentric uncles. We need to open those shoeboxes, snap the elastic bands and bring those notes of old weather records into the daylight.

Citation information

Cite this article as: Noble, Malcolm (2017) Answers in the wind: using local weather studies for family history research. Journal of Genealogy and Family History. 1(1). https:// dx.doi.org/10.24240/23992964.2017.030103

\section{References}

1. Burn, John Southerden. (1862) The history of parish registers in England. Republished 1976. Wakefield: E. P. Publishing.
2. Burn, John Southerden. (1862) The history of parish registers in England. Republished 1976. Wakefield: E. P. Publishing. p. 173.

3. Burn, John Southerden. (1862) The history of parish registers in England. Republished 1976. Wakefield: E. P. Publishing. p. 191.

4. Burn, John Southerden. (1862) The history of parish registers in England. Republished 1976. Wakefield: E. P. Publishing. p. 192.

5. Barmby, James. (1888) The churchwardens' accounts of Pittingdon and other parishes in the Diocese of Durham 1580-1700. Durham: Andrews \& Co. for the Surtees Society. p. 141. 
6. Cambridgeshire Family History Society. (1982) Bottisham Parish Registers (Transcript). CD/PR/84a CFHS. File on disc.

7. Lamb, Hubert and Frydendahl, Knud. (1991) Historic storms of the North Sea, British Isles and Northwest Europe. London: Cambridge University Press. p. 38

8. Simpson, Sue. (2016) Sir Henry Lee (1533-1611): Elizabethan courtier. London: Routledge. p. 122.

9. Burn, John Southerden. (1862) The history of parish registers in England. Republished 1976. Wakefield: E. P. Publishing. p. 184

10. Foster J. E., ed. (1890) The diary of Samuel Newton 1662-1716. London: Bell for Cambridge Antiquarian Society. p. 114.

11. Burn, John Southerden. (1862) The history of parish registers in England. Republished 1976. Wakefield: E. P. Publishing. p. 175

12. National Archives (Great Britain). [mid. 20th cent.] Notebook [containing details of visits to various schools in Suffolk and Cambridgeshire by a school inspector in geography to inspect lessons and equipment and snippets of news relating to weather and rainfall taken from Berrows Worcester Journal and the Worcestershire Herald 18061947]. Worcestershire Archive and Archaeology Services Ref 899:749/BA9509/xii.

13. Foster J. E., ed. (1890) The diary of Samuel Newton 1662-1716. London: Bell for Cambridge Antiquarian Society. p. 16

14. NASA. Climate. https://www.nasa.gov/mission_pages/noaa-n/climate/climate weather.html
15. Manley, G. (1953) The mean temperature of Central England 1698-1952. Quarterly Journal of the Royal Meteorological Society. 79. pp. 242-61.

16. Manley, G. (1974) Central England temperatures: monthly means 1659 to 1973. Quarterly Journal of the Royal Meteorological Society. 100. pp. 389-405.

17. Wortley, A. L. (1954) A history of Bingham. Oxford: Wortley. p. 35.

18. Burn, John Southerden. (1862) The history of parish registers in England. Republished 1976. Wakefield: E. P. Publishing. p. 175.

19. Foster, J. E., ed. (1905) Churchwardens' accounts of St Mary the Great Cambridge from 1504 to 1635. London: Bell for Cambridge Antiquarian Society. p. 307.

20. Testamentary records. England. 1574. TASSELL, William. Prerogative Court of Canterbury: Will Registers. PROB 11/57/261. The National Archives, Kew, England.

21. Hoskins, W. G. (1964) Harvest fluctuations and English economic history, 14801619. The Agricultural History Review. 12(1). pp. 28-46.

22. Marsh, Christopher W. (1994) The Family of Love in English society, 1550-1630 Cambridge: Cambridge University Press. pp. 72-4.

23. Marsh, Christopher W. (1994) The Family of Love in English society, 1550-1630. Cambridge: Cambridge University Press. pp. 72-4.

24. Metcalfe Walter C., ed. (1882) Visitations of Suffolk 1561-1612. Exeter: Pollard. p. 72

25. Iredale, David. (1980) Enjoying archives. $2^{\text {nd }}$ ed. London: Phillimore. pp. 20-32.

\section{ABOUT THE AUTHOR}

Malcolm Noble is an experienced crime writer who has repeatedly been in the top $12 \%$ of authors borrowed from UK libraries. In 2013 readers of the Historical Novels Society included him in their forty favourite authors, and he has been nominated for the Dagger in the Library Award. A series of his radio detective drama has been produced on $\mathrm{fm}$ radio. His monthly podcast for Genealogists with Too Much Time on Their Hands is now in its second year (talkgenealogy.wordpress.com). His privately published history, The Horsepools: Four Brothers and Cricket in Bingham, relates a sporting chapter (1800-32) in his family's past. His experience of family history goes back to the time when genealogists found a pair of wellingtons more useful than a laptop. For more information, visit malcolmnoble.com

Email: malcolm@bookcabin.co.uk

http://orcid.org/0000-0001-7572-4837 